\title{
SOME PARTICULAR ASPECTS OF THE AUTOMOTIVE INDUSTRY CONNECTORS'
}

\author{
Titu-Marius I. Băjenescu*, ORCID ID: 0000-0002-9371-6766 \\ Swiss Technology Association, Electronics Group Switzerland \\ ${ }^{*}$ Corresponding author: Titu-Marius I. Băjenescu, tmbajenesco@gmail.com
}

Received: 09. 29. 2021

Accepted: 11. 14. 2021

\begin{abstract}
Electrical connectors are very sensitive parts in an electronic system. The actual meaning of reliability and the problems associated with determining it, are often not right understood. The paper presents some particular aspects of the automotive industry connectors' i.e. fretting, fretting corrosion prevention, aluminium connections. The performance factors governed by the operating conditions and design-technology factors determined by the manufacturing characteristics of a contact unit were analyzed.
\end{abstract}

Keywords: Connector failures, microsensors and micromechatronic actuators, reliability, thick film technology, fretting, fretting corrosion, connector standards.

Rezumat. Conectoarele electrice sunt părți foarte sensibile într-un sistem electronic. Semnificația reală a fiabilității și problemele asociate cu determinarea acesteia adesea nu sunt înțelese corect. Lucrarea prezintă câteva aspecte particulare ale conectoarelor din industria auto și anume fretting, prevenirea coroziunii prin fretting, conexiuni din aluminiu. Au fost analizați factorii de performanță guvernați de condițiile de funcționare și factorii de proiectare-tehnologie determinați de caracteristicile de fabricație ale unei unități de contact.

Cuvinte cheie: Defecțiuni ale conectoarelor, microsenzori și actuatori micromecatronici, fiabilitate, tehnologie cu peliculă groasă, fretting, coroziune prin fretting, standarde pentru conectoare.

\section{Introduction}

Electrical connectors are a prerequisite for electrical and electronic connections. Basically the connector is a component which enables systems to be optimal used in the electrical energy transmission and the electronic and optical signal transmission. Electrical connectors are very sensitive parts in an electronic system [1]. The requirements specified for connector contacts in terms of wear resistance, wiping efficiency, corrosion resistance and mechanical stability are more or less stringent, depending on the intended use and environmental exposure. Contact between two cable terminals only occurs at small discrete spots where the asperities of the two surfaces meet [2].

Electric connectors (Figure 1) are an indispensable component of electronic circuits. Although connectors broadly fall into one of three categories: (i) wire / cable-to-wire/cable; (ii) wire / cable-to- board; and (iii) board-to-board connectors, precise definitions have not yet been established [3]. 


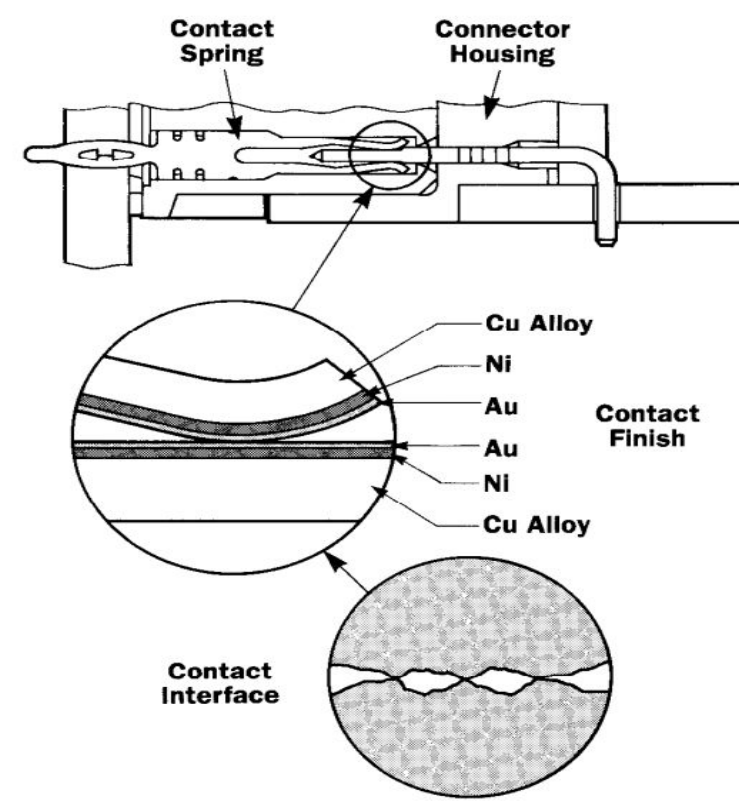

Figure 1. Typical connector indicating the major structural components (after [3]).

\section{Smart car connectivity}

Cars are in motion, roads are uneven, and this generates mechanical harmonics that could cause connectors to disengage over time. Currently, Smart Car connectivity occurs in two ways. Embedded cars utilise a built-in radio and antenna connecting to local cellular networks, while tethered cars use a wireless connected device, typically a cell phone, to provide the data connectivity [4]. Cameras are the optical sensor portion of the sensor suite required for higher levels of autonomy. Currently, most cameras are used for vision systems and basic safety features such as parking assistance. As future cameras are designed and deployed with a requirement for higher data rates due to high resolutions like $4 \mathrm{~K}$ or stereo image streams, there will be a need for the connectors and cable to support greater than 6 $\mathrm{GHz}$. The other significant growth area driven by the development of autonomous vehicles is data communication: vehicle to vehicle and vehicle to infrastructure.

Autonomous capability requires vast and comprehensive information to enable robust Artificial Intelligence (Al) decisions. The cameras and other sensors will be supplemented by large streams of data from wireless sources. Real time information from other vehicles and infrastructure will supply the Al module with the latest critical information from nearby $5 \mathrm{G}$ devices and the cloud [5]. The vehicle accesses these data streams with multiple antennas either dispersed or consolidated into smart antennas. Smart antennas reduce the amount of cabling in the vehicle, further reducing cost and weight, but add a complexity in connecting the antenna signals to the processing boards.

The automotive landscape is rapidly transforming, as autonomous systems, electric drive trains, and tech-enhanced interiors become part of the car experience across makers and price points. Future car technologies are arriving now, thanks to precision automotive connectors. These must be optimized to withstand the automotive harsh environments, which include shock, vibration, temperature extremes, moisture, and ingress by dirt and other particulates. High speed, high frequency connectors must handle significant amounts of invehicle data as well as transit information to data centres and cloud computer facilities [6]. Connectors need to be accessible, easy to handle, and easy to swap out in the event of damage. 
Connectors must be able support a wide variety of sensors types and rapidly and reliable transfer large amounts of data. Even as connectors become smaller and lighter, highquality contacts and secure locking features remain critical. Connectors involved in charging systems must be ruggedized to endure thousands of charging cycles [7].

Connectors are indispensable for safe data and reliable power transmission in automobiles. In the networking of tomorrow's production, connection technology is the main interface between machines, controls and data processing systems. Reliable plug connections in automotive and industrial applications, and form the basis for functionality, easy handling and reliability of the expenditure to be fulfilled.

The digitized wiring system is one of the most important function carriers within autonomous automobiles as well as automation systems. The products are differentiated not only by price, but in particular by attributes and additional benefits such as technical reliability and innovation, ease of use and compact design [8]. Connectors are evaluated for a number of cycles from a single use to several thousand.

New connection technologies and integration techniques are being researched in order to implement intelligent connectors with sensors and actuators [9]. Typical failures, due to friction corrosion or chemical corrosion, have short notice times and still know how to lead to failure of important systems. An integrated monitoring of the current connection quality through integrated, miniaturized electronic sensor systems could help.

Improving products, finding out technical connections, developing new technologies and then vividly passing on these findings to the next generation of engineers - this is what drives today.

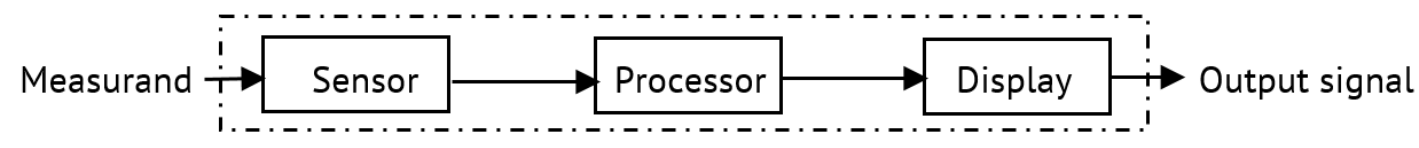

Figure 2. From measuring to output signal.

In addition to the pressure from emission regulations, a political and regulatory trend towards the promotion of electric vehicles is also emerging internationally. Recent reports speak of a ban on vehicles with combustion engine in Norway from 2025 and in France and Great Britain from 2040. To what extent these plans will be implemented, remains to be seen. For this reason, the strategies of major automobile manufacturers focus on the development of electric drives. Car manufacturers are currently reacting to the trend towards electrified vehicles with a development offensive. To ensure that all components are electrically safe and separable from each other, various plug connections are used in the low-voltage and highvoltage range.

Through vibration tests, contact resistance measurements and SEM images, it was possible to find relationships between sliding distance, number of oscillations and electrical resistance increase [10]. In vehicle construction, a fatigue strength analysis includes not only the validation of "classic", time-varying operational stresses, but also the consideration of special events when used as intended (e.g. slow obstacle crossing of potholes or similar), abuse events (e.g. fast obstacle crossing), creep or wear (e.g. joint wear of chassis components).

From material development and simulation of vehicle bodies known multi-level principles are to be further developed, transferred to the operational stability analysis of high-voltage accumulators and plug contacts in an interdisciplinary manner and oriented to the multi-scale structure of the components as well as to the existing stress situations and damage mechanisms [11]. 


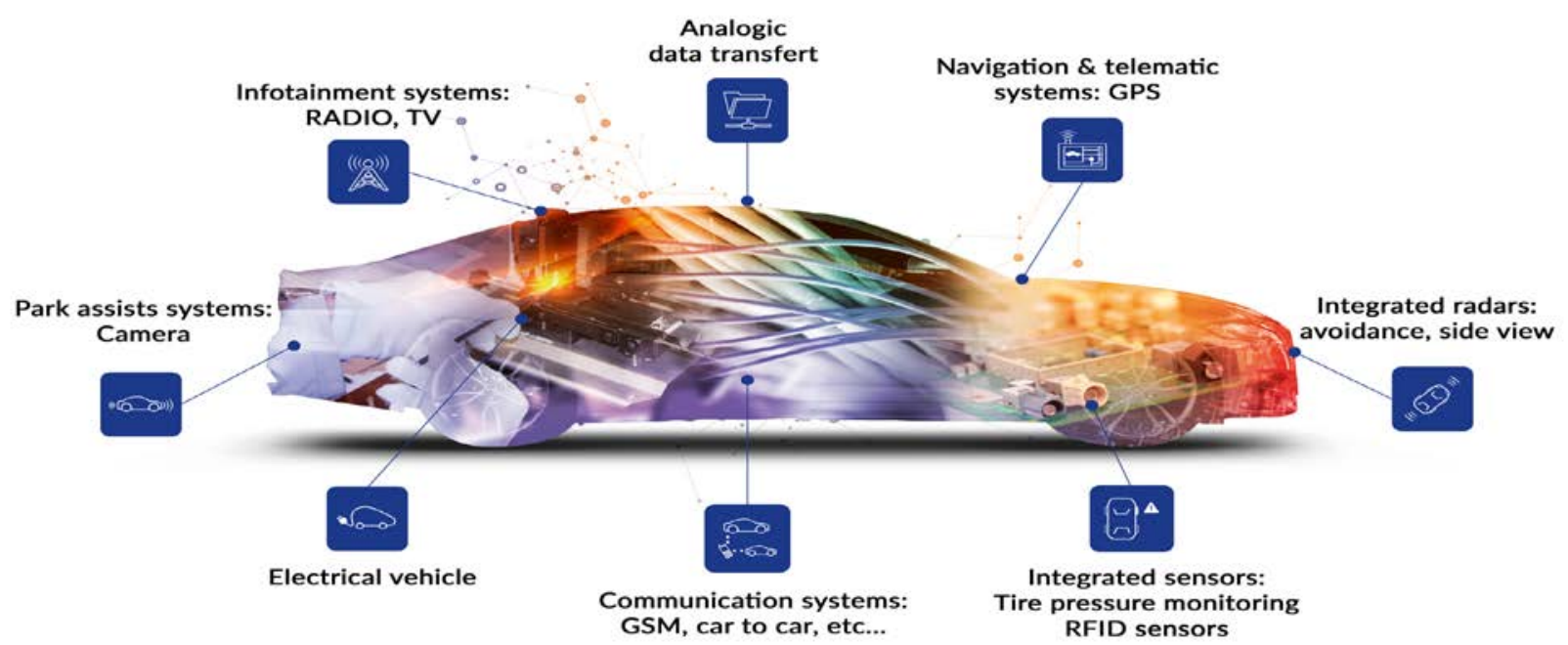

Figure 3. Some examples of connectors utilized in automotive industry [after 10].

Optical measurement methods are usually ruled out in practice due to excessive complexity, lack of reliability for measurements in the engine compartment and poor accessibility of components and measuring points.

\section{Reliability aspects}

There are two aspects to ensuring connector reliability: building reliability into the connector through materials and design choices, and assessing that reliable performance has been realized $[8,12]$.

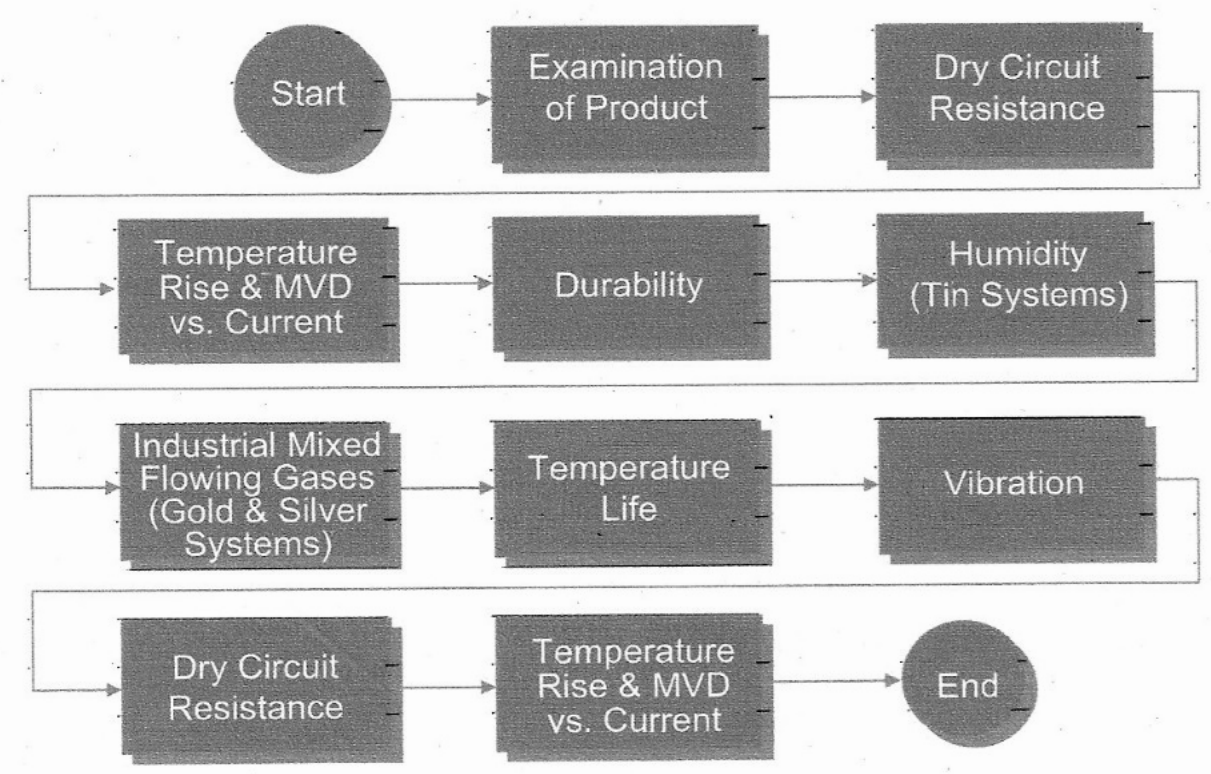

Figure 4. Reliability assessment testing.

Today's contact families using high-performance alloys (e.g. CuNiSi) are considerably more current-carrying than previous systems.

In the so-called reliability concept of measurement, securities and valuations are always determined on the basis of probabilities and calculated scatters [11]. The reliability concept cannot only be to the fatigue-resistant design, but also to the operation-resistant design with damage calculations. 


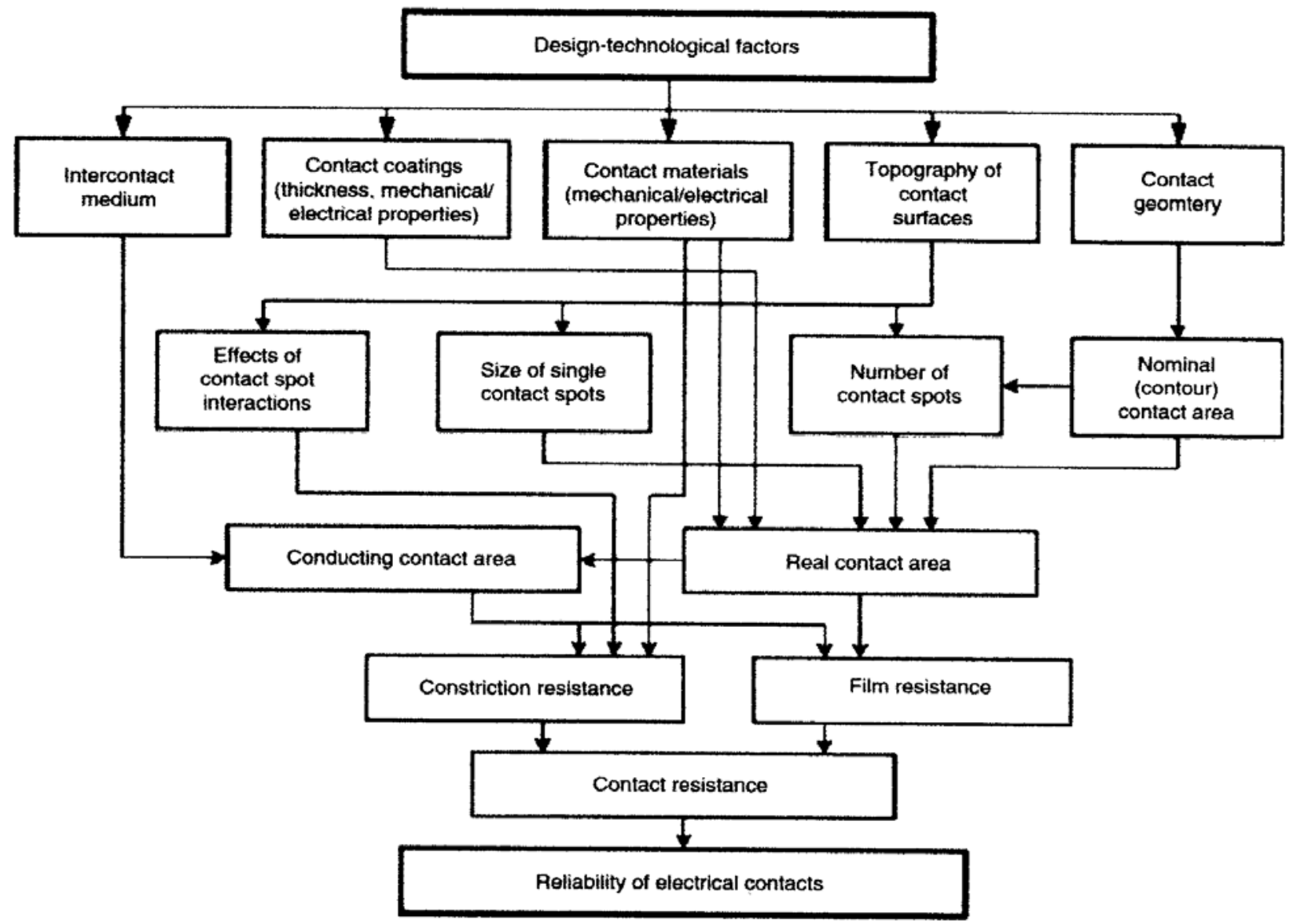

Figure 5. Effect of performance factors on the reliability of electrical contacts (after [11]).

\section{Factors affecting reliability}

The variety of the factors can be conventionally divided into (1) the performance factors governed by the operating conditions and (2) the design-technological factors determined by the fabrication characteristics of a contact unit [13]. The performance factors (parameters) are divided basically into two groups: internal and external (Figure 5).

The performance factors affect the properties of contact materials and surface films, the occurrence of physical and chemical processes in the contact zone, wear particle formation thus influencing the state of the interface and, finally, the contact resistance and reliability of electrical contacts [14 - 16].

Failure causes and mechanisms: 1. Mating/unmating cycling increases oxidation susceptibility by erosion/corrosion of protected layer. 2. Temperature. - The effect of temperature in connector is stress relaxation. $\bullet$ Stress relaxation results in loss of the normal force, which in turns increases the contact resistance. $\bullet$ Nickel oxidation. 3. Humidity. $\bullet$ The major effect of humidity on metal contacts is possible corrosion. • A decrease in contact resistance occurs with humidification and an increase in resistance occurs with dehumidification [19].

There were many researchers who among the years were investigating this phenomenon and associated issues giving the foundations of science, which is today called "tribology". The fretting nowadays is a term, which is used in reference to the situation where two bodies staying in contact experience a small relative movement (Figure 9) [Eden et al.] [Tomlinson]. 

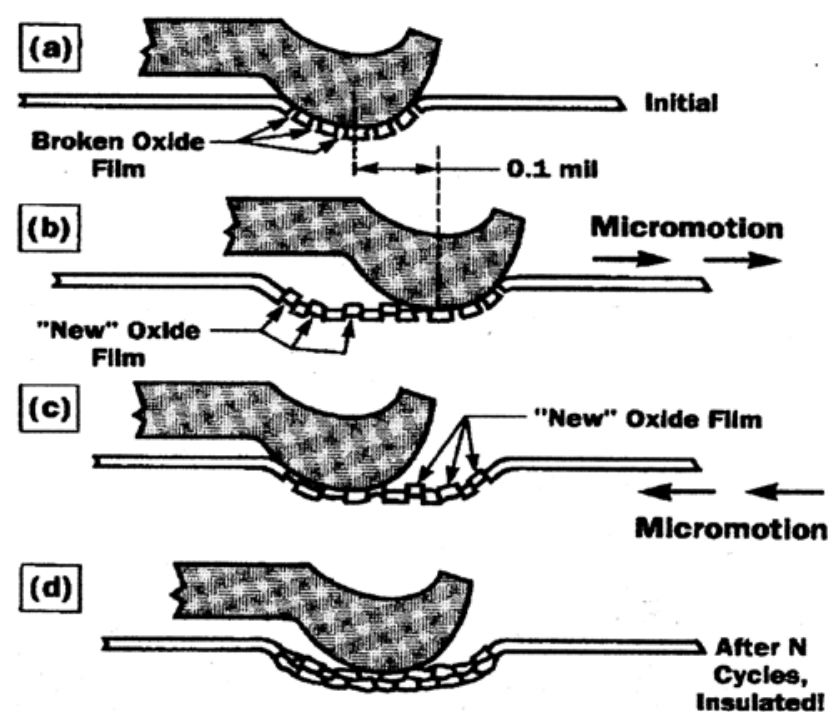

Figure 6. Schematic illustrations of the mechanisms of fretting.

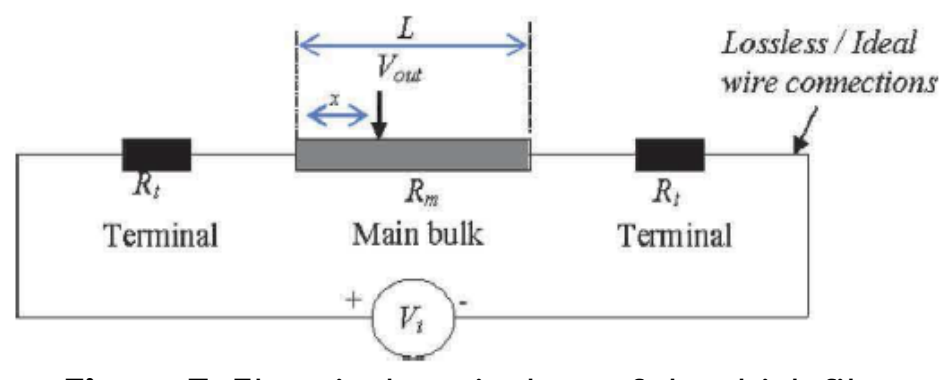

Figure 7. Electrical equivalent of the thick film sensor.

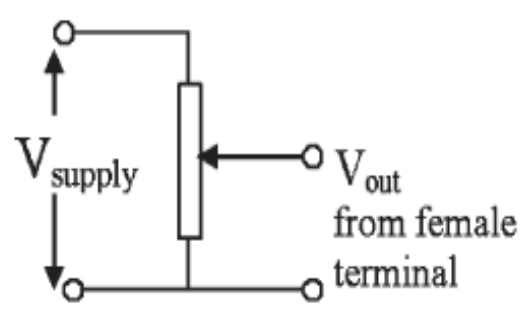

Figure 8. Schematic representation of sensor's working principle.

\section{Fretting}

Fretting as a phenomenon of the wear of the surface of contacting bodies was first observed by Eden. He confirmed the presence of iron oxide debris between the two samples subjected to a relative motion. It is Tomlinson who is considered the father of the definition and the term "fretting".

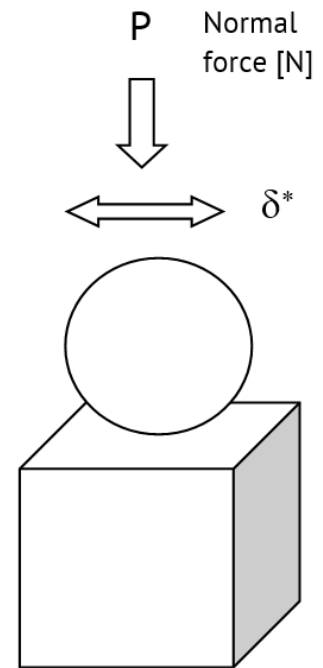

Figure 9. Illustration of the sphere/plane contact subjected to the freeting loadings. $\delta^{*}$ displacement amplitude $[\mu \mathrm{m}]$.

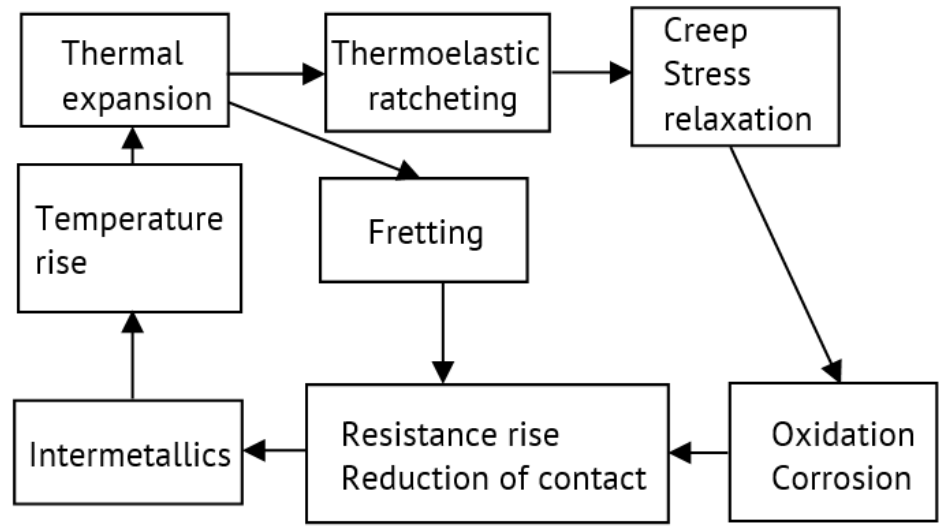

Figure 10. Schematic of degradation mechanisms in aluminum connections. 
The three basic reference contact geometries that are usually used are (1) cylinder/plane, (2) plane/plane, and (3) sphere/plane. Although the plane/plane geometry is the easiest, from a mechanical point of view, the discontinuity of the pressure on the border of the contact makes the analysis of the contact very complicated. To simplify the analysis, two remaining geometries are used to investigate the fretting phenomenon. The simplicity of the contact mechanics and ease of application make them the most popular configurations for research on fretting and contact mechanics. The cylinder/plane geometry describes the 2D linear contact situation. The distribution of the stress and elastic deformations are very well described by the theory of Hertz. The cylinder/plane geometry is often used in the research on the cracking and crack propagation since it enables two-dimensional approach which can be modelled by the finite element method [Hertz][Proudhon].

The complexity of failure mechanisms in aluminum power connections is best depicted in the course of a cycle, as shown in Figure 10.

\section{Fretting corrosion prevention}

Fretting is wear or corrosive damage responding to the roughness of contact surfaces. This damage results under load and in the presence of repetitive surface motion conditions. Vibration can also cause a fretting condition. The traditional failure mode in tin-plated connections is fretting corrosion [21 - 23]. The Micro-MaTch connector assists in preventing such corrosion. Because of the female part's additional positioning spring, the Micro-MaTch connector absorbs relative vibration and thermal-expansion movements between male and female contacts. This configuration of connectors creates an airtight connection, as it prevents contact spot movements (Figure 11).

The Micro-MaTch contact spring system is resistant to fretting corrosion. In this system, the positioning spring compensates positional tolerances and provides the tin-plated contact system's high contact force [6].
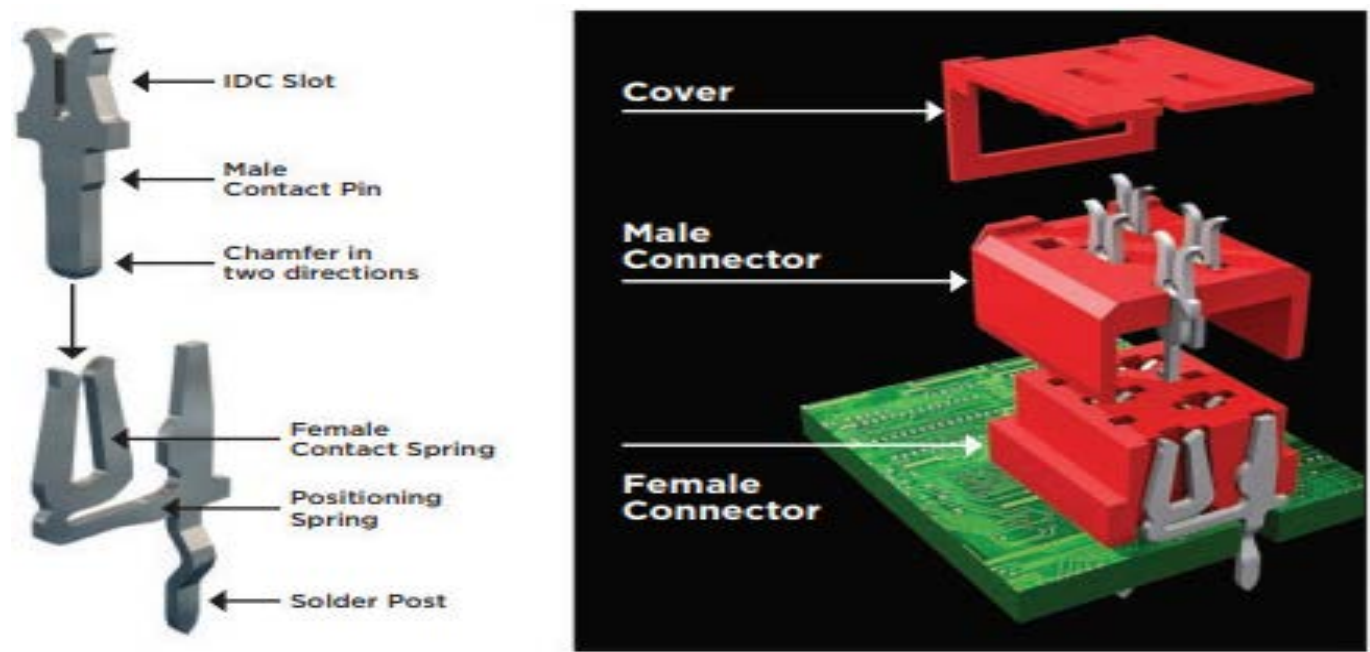

Figure 11. The connector socket has a contact spring system that acts to create a socket with fretting-corrosion resistance [6].

\section{Conclusions}

In order to reduce wear and corrosive damage, it is necessary to test and operate them according to the connectors standards:

- IEC 61586 provides the most extensive reliability testing protocol.

- There is a basis of agreement to develop standard reliability testing protocols. 
- EIA 364F: Electrical Connector/Socket Test Procedures Including Environmental Classifications.

- EIA 364-1000: Environmental Test Methodology for Assessing the Performance.

- ISO/IEC TR 29106: Introduction to MICE Environmental Classification.

- IEC 61586-TS: Estimation of the Reliability of Electrical Connectors.

\section{References}

1. Erjavec J., Thompson R. Automotive Technology. A systems approach. In: $6^{\text {th }}$ Edition, 2015, Delmar.

2. Băjenescu T.-M. I. Zuverlässige Bauelemente für elektronische Systeme. In: Springer-Verlag, 2020

3. Minoru Aoyagi, Takahiro Ueno, Makoto Okuda. Automatic Detection System for Complete Connection of a Waterproof Soft Shell Electronic Connector With a Sliding Locking Device. In: IEEE Sensors Journal, 2009

4. Varde P. V., Agarwal M., Marathe P. P., Mohapatra U., Sharma R. C., Naikan. V. N. A. Reliability and Life Prediction for Electronic Connectors for Control Applications. In: 2nd International Conference on Reliability, Safety and Hazard - Risk-Based Technologies and Physics-of-Failure Methods (ICRESH), 2010

5. Băjenescu T.-M. I. The Electric Connectors in the Digitized World. In: EEA 68(2020), nr. 4, pp. 37-43

6. Baker B. Reliable Connectors Keep Industrial Robotics Moving Efficiently. In: Electronicdesign.com p. 2

7. Mroczkowski R. S. Connector Design/Materials and Connector Reliability. In: AMP Tech. Pap. P, 1993, pp. 351-393

8. Mroczkowski R. S. A Perspective on Connector Reliability, http://www.ieee-holm.org/h2004/h2004antler. pdf

9. Zhang Zhige, Lam Liza, Atkinson John and Maul Christian, Miniature Thick Film Position Sensor for Real Time. In: situ Monitoring at the Contact Point of Automotive Connectors, Vol. 16(2005), No. 8

10. Varde P. V., Agarwal M. P. P., Marathe U., Mohapatra R. C., Shanna and V. N. A. Naikan. Reliability and Life Prediction for Electronic Connectors for Control Applications. In: 2010 2nd International Conference on Reliability, Safety and Hazard - Risk-Based Technologies and Physics-of-Failure Methods (ICRESH)

11. Braunovic Milenko. Power Connectors, Electrical Contacts Principles and Applications Second Edition, 2014

12. Wise J. H., Mroczkowski R. S. (Eds.). Connector Types. In: Electronic Connector Handbook. New York, McGrawHill, 1998, ch. 13

13. Braunovic Milenko. Reliability of Power Connections. In: Journal of Zhejiang University SCIENCE A, 2007.

14. Lam L., McBride J. W., Maul C., Atkinson J. K. Displacement Measurements at the Connector Contact Interface Employing a Novel Thick Film Sensor. In: Proc. of the Fifty-First IEEE Holm Conference on Electrical Contacts, 2005

15. Braunovici Milenko. Fretting in Electrical/Electronic Connections: A Review. In: IEICE Transactions, August 2009

16. Eden E. M., Rose W. N., Cunningham F. L. The Endurance of Metals. In: Proc. Instn Mech. Engrs, 1911, pp. 875

17. Hertz H. Über die Berührung fester elastischer Körper. J. Reine und Angewandte Mathematik 92, 156-171 (1882)

18. Kong Zhigang, Jonathan Swingler. Combined effects of fretting and pollutant particles on the contact resistance of the electrical connectors. In: Progress In Natural Science: Materials International, 26 May 2017

19. Nelson Wayne. Accelerated testing statistical models, test plans, and data analysis. In: John Wiley \& Sons, 2004

20. Proudhon $\mathrm{H}$. Identification des mécanismes de fissuration dans un alliage d'aluminium sollicité en fretting et en fatigue. Ph. D. Thesis, Institut National des Sciences Appliquées de Lyon, 2005

21. Swingler J., McBride John W. and Maul Christian. Degradation of Road Tested Automotive Connectors. In: IEEE Transactions on Components and Packaging Technologies, Vol. 23, No. 1, March 2000

22. Tomlinson G. A. The Rusting of Steel Surfaces in Contact. In: Proc. of Royal Society, 1927, A 115, pp. 427483

23. White N. M. Thick Film Technology. In: Prudenziati M., (Ed.), Thick Film Sensors, Elsevier, Amsterdam, 1994 